\title{
NF-KB repressing factor downregulates basal expression and mycobacterium tuberculosis induced IP-10 and IL-8 synthesis via interference with NF-KB in monocytes
}

\author{
Kuo-Hsiung Huang ${ }^{1}$, Chun-Hua Wang ${ }^{2,3}$, Chien-Huang Lin ${ }^{1 *+}$ and Han-Pin Kuo ${ }^{2,3^{*+}}$
}

\begin{abstract}
Background: Our previous study showed NF-KB repressing factor (NKRF) downregulates IP-10 and IL-8 synthesis in the peripheral blood mononuclear cells and alveolar macrophages of TB patients with high bacterial loads. However, the mechanism underlying the repressive effect of NKRF is not fully understood.

Results: The levels of IP-10, IL-8 and NKRF were significantly up-regulated in THP-1 cells treated with heated mycobacterium tuberculosis (H. TB). NKRF inhibited NF-KB-mediated IP-10 and IL-8 synthesis and release induced by $\mathrm{H}$. TB. The repressive effect of NKRF is mediated via interference with NF-KB (p65) binding and RNA polymerase II recruitment to promoter sites of IP-10 and IL-8.

Conclusions: We have elucidated that direct contact with MTb induces IP-10, IL-8 and a concomitant increase in NKRF in THP-1 cells. The up-regulated NKRF serves as an endogenous repressor for IP-10 and IL-8 synthesis to hinder host from robust response to MTb infection.
\end{abstract}

Keywords: Tuberculosis, IP-10, IL-8, NF-KB repressing factor

\section{Background}

Tuberculosis (TB) killed an estimated 100 million people over the last century [1-3]. About one third of the world's population is infected with Mycobacterium tuberculosis (MTb). Most of the infected persons never develop an active disease [1-3] because the host immune response keeps the infection under control. After MTb infection, innate immunity initially predominates the subsequent response in the host. For the purpose to contain MTb, T lymphocytes are recruited to the lung within granulomas, which consist of activated macrophages, $\mathrm{T}$ lymphocytes, fibroblasts, and epitheloid cells [4]. To prevents the disease reactivation, a complex interaction between different cell populations are involved in the control of MTb infection.

\footnotetext{
* Correspondence: chlin@tmu.edu.tw; q8828@ms11.hinet.net

${ }^{\dagger}$ Equal contributors

${ }^{1}$ Graduate Institute of Medical Sciences, College of Medicine, Taipei Medical University, 250 Wu-Hsing Street, Taipei 110, Taiwan

${ }^{2}$ Pulmonary Medicine Research Center, Chang Gung Memorial Hospital,

Taipei, Taiwan

Full list of author information is available at the end of the article
}

Specific chemokines, such as IP-10, IL-8, MIG/CXCL9 and MCP-1/CCL2 are released from monocytes, alveolar macrophages and polymorphonuclear granulocytes to recruit NK cells, $\gamma \delta$ T lymphocytes, and $\alpha \beta$ T lymphocytes of $\mathrm{CD}^{+}$and $\mathrm{CD}^{+}$phenotypes in sequential order into the site of MTb infection [5-9].

IP-10, a member of the $\alpha$-chemokine subfamily, is involved in delayed type hypersensitivity [10]. It promotes Th1 responses and IFN- $\gamma$ gene expression [11], and attracts monocytes and activated $\mathrm{T}$ lymphocytes to inflammatory foci [12]. High levels of IP-10 were detected in TB patient's sera $[13,14]$ and bronchoalveolar lavage $[13,15]$. Except for chemotaxis, IP-10 also contributes to the necrosis of tuberculous granulomas by inhibiting angiogenesis [16].

Enhanced IL-8 release and gene expression in macrophages or monocytes has been shown after exposure to MTb and its components $[17,18]$. IL-8 gene polymorphism is associated with susceptibility to TB [19], and in HIVinfected patients [20]. IL-8 is necessary for granuloma 
formation [21], limits the growth of intracellular MTb, and enhances the abilities in macrophage killing MTb [22].

The induction of both IP-10 and IL- 8 by MTb is NF- $\mathrm{KB}$ dependent $[16,23]$. Our previous study showed NF-kB repressing factor (NKRF) is upregulated in the circulating monocytes and alveolar macrophages of patients with active pulmonary $\mathrm{TB}$, and inhibits synthesis and release of IP-10 and IL-8 [13]. NKRF is a transcriptional silencer and is implicated in the basal silencing of specific NF- $\mathrm{kB}$ targeting genes, including iNOS, IFN- $\beta$ and IL-8 [24-26]. NKRF only interacts with specific NRE (negative regulatory element) to mediate NF- $\mathrm{KB}$ transcriptional silencing. NKRF specific NREs are only found in certain NF- $\mathrm{KB}$ transcriptional genes in certain cells [24-26]. However, the mechanism underlying NKRF up-regulation and its silencing effect on IP-10 and IL-8 in MTb infected monocytes has not been clearly explored. In the present study, we have demonstrated that direct exposure to MTb upregulates NKRF expression in monocytes, and the repressive effect of NKRF on IP-10 and IL-8 synthesis might be via interfering with NF- $\mathrm{kB}$ (P65) binding and RNA polymerase II recruitment to their promoter sites.

\section{Methods}

\section{Cell preparation and culture}

THP-1 cells purchased from the ATCC (TIB202) were grown in suspension in T-150 tissue culture flasks in RPMI 1640 (GIBCO, Grand Island, NY, USA) supplemented with $10 \%$ fetal calf serum (FCS, Flow Laboratories, Paisley, Scotland, UK). Cells $\left(1 \times 10^{6}\right.$ cells $\left./ \mathrm{ml}\right)$ were pretreated with or without NF- $\mathrm{KB}$ specific inhibitor Helenalin (Merck KGaA, Darmstadt, Germany) half hour before incubation with or without heated TB bacilli (H37-RA) (H. TB) (DIFCO) for various time points (6, 24, $72 \mathrm{hrs).}$ The culture supernatant was collected and frozen at $-70^{\circ} \mathrm{C}$ before analysis for assay of IP-10 and IL-8 by ELISA with commercial ELISA kits (R\&D Systems, Minneapolis, MN). The levels of cytokine secretion could vary among different passages of the target cells, e.g., THP-1 cells. In each experimental study, the same passage of cultured cells was used to minimize the variation. The control group from the same passage was used to justify a similar response as that in different passage of cultured cells.

\section{Quantitative real-time PCR (qPCR)}

Total RNA was isolated from cells using TRIzol reagent (Invitrogen, Grand Island, NY) according to the manufacturer's instruction. cDNA was reversely-transcribed from isolated RNA by incubating $200 \mathrm{ng}$ of DNase-treated RNA with the first-strand synthesis kit (Advanced Biotechnologies). qPCR was performed in a LightCycler 2.0 System (Roche Applied Science) using LightCycler DNA Master SYBR Green I (Roche Applied Science). Samples were denatured at $95^{\circ} \mathrm{C}$ for $10 \mathrm{~min}$, followed by 45 cycles of annealing and extension at $95^{\circ} \mathrm{C}$ for $15 \mathrm{~s}, 60^{\circ} \mathrm{C}$ for $5 \mathrm{~s}$, and $72^{\circ} \mathrm{C}$ for $10 \mathrm{~s}$. Melting curves were obtained at the end of amplification by cooling the samples to $65^{\circ} \mathrm{C}$ for $15 \mathrm{~s}$, followed by further cooling to $40^{\circ} \mathrm{C}$ for $30 \mathrm{~s}$.

Data were analyzed by standard curve method of relative quantification using the LightCycler analysis software.

\section{Quantification of NF-KB p65 DNA-binding activity (TransAM assay)}

To determine the alteration of NF- $\mathrm{KB}$ activity by MTb in THP-1 cells, the level of NF-kB subunits p50, p52, p65, $\mathrm{C}-\mathrm{Rel}$ and RelB activity was measured using the NF- $\mathrm{kB}$ TransAM kit (Active Motif) according to the manufacturer's instructions. Briefly, cells nuclear extraction were prepared by using the Nuclear Extract Kit (Active Motif) and protein concentrations were measured using the Bradford assay (Bio-Rad). Lysates (10 $\mu$ g total proteins) were incubated in ELISA wells coated with the NF- $\mathrm{kB}$ consensus site ( $5^{\prime}$ - GGGACTTTCC $-3^{\prime}$ ) recognized by active NF- $\mathrm{kB}$ subunits p50, p52, p65, C-Rel and RelB, then they were detected using a specific antibody, followed by a secondary antibody conjugated to peroxidase.

\section{Immunostaining and confocal microscopic analysis}

THP-1 cells treated with or without $\mathrm{H}$. TB were spun down on slide then fixed in methanol at $-20^{\circ} \mathrm{C}$ for $5 \mathrm{~min}$. The cells were then blocked with $1 \%$ BSA/PBS at room temperature for $30 \mathrm{~min}$ and incubated with the rabbit anti human NKRF Ab at room temperature for $1 \mathrm{hr}$. After washing, the cells were incubated with a Cy3-conjugated anti-rabbit $\mathrm{Ab}$ (Chemicon International) and incubated with Hoechst dye (Sigma-Aldrich). After washing and airdrying, the cells were mounted with anti-fade mounting medium (Dako Cytomation). Images were acquired with a confocal laser-scanning microscope (Leica) and analyzed by Metamorph Image Analysis (Universal Imaging).

\section{Western blot analysis}

Total cellular proteins were extracted from THP- 1 cells by freeze-thawing samples in Reporter lysis buffer (Promega). Proteins were subjected to 7.5\% SDS-PAGE and blotted onto nitrocellulose filters. NKRF was detected with $\beta$-actin (sigma) and an alkaline phosphatase-conjugated anti-mouse secondary Ab (1/100,000 dilution; Calbiochem) or specific anti-NKRF $\mathrm{Ab}$ and an alkaline phosphatase-conjugated anti-rabbit secondary $\mathrm{Ab}$ (1/10,000 dilution; Calbiochem). Blots were incubated with ECL solution (LumiGLO; Amersham Bioscience). Images were acquired and analyzed using G: BOX (Syngene).

\section{Transfection of siRNA and plasmids}

To knockdown NKRF expression, Si-RNA (Si-Scramble and Si-NKRF) were introduced into THP-1 cells. Plasmid DNA (p-CMV and p-CMV-NKRF) were introduced into 
THP-1 cells to evaluate whether NKRF overexpression can regulate the release of IP-10 and IL- 8 . The transfection of THP- 1 cells $\left(1 \times 10^{6}\right.$ cells $\left./ \mathrm{ml}\right)$ was performed by lipofectamine 2000 kit (Invitrogen, Grand Island, NY). We diluted 20 pmol siRNA oligomer (or $1 \mu \mathrm{g}$ plasmid DNA) in $50 \mu \mathrm{l} \mathrm{Opti-MEM} \mathrm{medium} \mathrm{(Invitrogen,} \mathrm{Grand} \mathrm{Island,}$ $\mathrm{NY}$ ) without serum to mix gently. Then, $1 \mu$ l Lipofectamine 2000 in $50 \mu \mathrm{l}$ Opti- MEM medium was diluted to mix gently and incubate for 5 minutes at room temperature. The diluted oligomer and diluted Lipofectamine 2000 were mixed and incubated for 20 minutes at room temperature. We added the oligomer (DNA)- Lipofectamine 2000 complexes to each well containing $0.5 \mathrm{ml}$ cells and medium. The cells were incubated at $37^{\circ} \mathrm{C}$ in a $\mathrm{CO}_{2}$ incubator for $6 \mathrm{hrs}$. After transfection, cells were incubated in complete medium for $48 \mathrm{hrs}$ (for si-RNA) or 24 hrs (for plasmid DNA). The transfection efficiency in THP-1 cells was $53.4 \%$ for siRNA and $56.3 \%$ for plasmid DNA. The supernatant of cell after 6 hrs culture was collected for ELISA. The protein of transfected THP-1 cells was harvested for Western blot analysis.

\section{Chromatin immunoprecipitation (ChIP) assay}

ChIP assays were preformed as described previously $[13,27]$. After stimulation, protein-DNA complexes were cross-linked at $37^{\circ} \mathrm{C}$ for $10 \mathrm{~min}$ by formaldehyde $(1 \%$ final concentration). Twenty $\mu \mathrm{l}(1 \%)$ of ChIP dilution solution was kept as input control. The remained diluted solution was precleared by incubating with $80 \mu \mathrm{l}$ of salmon sperm DNA/protein A-agarose-50\% slurry for $30 \mathrm{~min}$ at $4^{\circ} \mathrm{C}$ on a rotator. After centrifuge, $900 \mu \mathrm{l}$ of the supernatant was immunoprecipitated at $4^{\circ} \mathrm{C}$ overnight on a rotator by using Abs specific for NKRF $(5 \mu \mathrm{g})$, IgG (Santa Cruz Biotechnology) followed by incubation for $1 \mathrm{hr}$ at $4^{\circ} \mathrm{C}$ with $60 \mu \mathrm{l}$ of salmon sperm DNA/protein A-agarose-50\% slurry. Protein-bound immunoprecipitated DNA (IP-DNA) was sequentially washed with low-salt or high-salt immune complex wash buffers. Immune complexes were eluted twice by adding $250 \mu \mathrm{l}$ of elution buffer (1\% SDS/0.1 M NaHCO3). DNA-protein cross-links were reversed by incubation for $4 \mathrm{hrs}$ at $65^{\circ} \mathrm{C}$ in $200 \mathrm{mM} \mathrm{NaCl} /$ $1 \% \mathrm{SDS}$, and proteins were digested by incubation for $1 \mathrm{hr}$ at $45^{\circ} \mathrm{C}$ with $70 \mu \mathrm{g} / \mathrm{ml}$ proteinase K (Sigma-Aldrich). DNA was isolated with phenol/chloroform, precipitated with ethanol/0.3 M NaHCOOH/20 $\mu$ g of glycogen and was resuspended in $50 \mu \mathrm{l}$ of nuclease- free water. qPCR was performed with $7 \mu$ of DNA sample for quantification.

\section{Statistical analysis}

Data were expressed as mean $\pm \mathrm{SE}$. The data were analyzed with Student's $t$ test for paired or unpaired data. For data with uneven variation, the Mann-Whitney $U$ test or Wilcoxon's signed ranks test was used for unpaired or paired data, respectively. Statistical significance of results was determined using prism4 software. A value of $\mathrm{p}<0.05$ was considered statistically significant.

\section{Results}

Increased mRNA expression and protein release of IP-10 and IL-8 in H. TB treated THP-1 cells

After treatment with or without H. TB, THP-1 cells were harvested for q-PCR and the supernatant was collected for ELISA. The expression of mRNA and NF- $\mathrm{kB}$ subunit activation were observed at 2 hour, while protein expression and ChIP assay were observed at 6 hour and 1 hour, respectively throughout the study. The viability determined by MTT assay was significantly decreased when THP-1 cells treated with $20 \mu \mathrm{g} / \mathrm{ml} \mathrm{H}$. TB $(81.7 \pm 1.0 \%$ of control) (Figure 1A). Among non-cytotoxic concentrations $(\mathrm{H}$. TB 2.5, 5, $10 \mu \mathrm{g} / \mathrm{ml}), 10 \mu \mathrm{g} / \mathrm{ml}$ induced the maximal and $5 \mu \mathrm{g} / \mathrm{ml}$ induced the submaximal cytokines secretion responses. We therefore defined H. TB $10 \mu \mathrm{g} / \mathrm{ml}$ as the highest non-cytotoxic concentration and $5 \mu \mathrm{g} / \mathrm{ml}$ as submaximal concentration in this study. H. TB induced increases in the levels of mRNA and protein of IP-10 and IL-8 in a concentration-dependent manner (Figures 1B, $\mathrm{C})$. When treatment with $\mathrm{H}$. TB for $2 \mathrm{hrs}$, the mRNA levels of IP-10 significantly increased at $5 \mu \mathrm{g} / \mathrm{ml}$ of $\mathrm{H}$. TB $(\mathrm{n}=5)$, reaching the maximum at $10 \mu \mathrm{g} / \mathrm{ml}(\mathrm{n}=5)$ (Figure $1 \mathrm{~B})$. The levels of IL-8 mRNA significantly increased at $2.5 \mu \mathrm{g} / \mathrm{ml}$ of $\mathrm{H}$. TB $(\mathrm{n}=5)$, reaching the maximum at $10 \mu \mathrm{g} / \mathrm{ml}(\mathrm{n}=5)$ (Figure 1B), when compare to the vehicle controls $(n=5$, $\mathrm{P}<0.05$ respectively). When treatment with $\mathrm{H}$. TB for 6 hrs, the protein of IP-10 significantly increased at $2.5 \mu \mathrm{g} / \mathrm{ml}$ of $\mathrm{H}$. TB, reaching the maximum at $10 \mu \mathrm{g} / \mathrm{ml}$ when compared with vehicle control (Figure $1 \mathrm{C}$ ). The protein of IL-8 also significantly increased at $2.5 \mu \mathrm{g} / \mathrm{ml}$ of $\mathrm{H}$. TB, reaching the maximum at $20 \mu \mathrm{g} / \mathrm{ml}$ when compared with vehicle controls (Figure 1C).

Increased NF-KB subunits, and the role of NF-KB inhibitor in the release of IP-10 and IL-8 in H. TB treated THP-1 cells

This study was designed to examine the modulatory role of NKRF in regulation of IP-10 and IL-8. Therefore, a submaximal concentration at $5 \mu \mathrm{g} / \mathrm{ml}$ was used to examine the mechanisms for NKRF implicated in suppression of IP-10 and IL-8 gene activation via an interference with NF- $k B$ p65. TransAM assay in THP-1 cells stimulated with $\mathrm{H}$. TB $(5 \mu \mathrm{g} / \mathrm{ml})$ for $2 \mathrm{hrs}$ revealed an increase in NF-kB subunits p65, p52, p50, C-Rel and RelB, respectively $(\mathrm{p}<0.05, \mathrm{n}=5)$ compare to vehicle control (Figure 2A). THP-1 cells pretreated with a specific NF- $\mathrm{kB}$ inhibitor, Helenalin $(0.5 \mu \mathrm{M})$, suppressed $\mathrm{H}$. TB induced IP-10 and IL-8 release compared with those of control (Figure 2B), indicating the release of IP-10 and IL- 8 is mediated via NF- $k B$. There was no significant cytotoxicity induced by $0.5 \mu \mathrm{M}$ Helenalin (cell viability $>96 \%$, data not shown). 


\section{A}

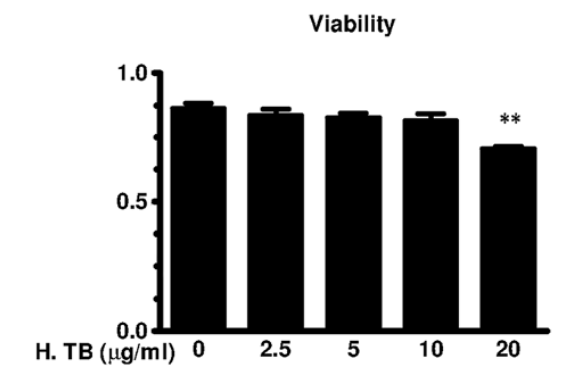

B

IP-10

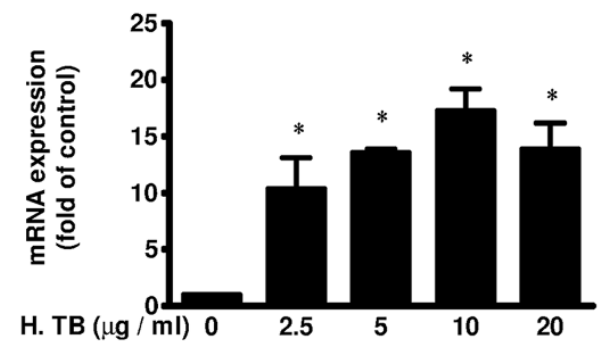

C

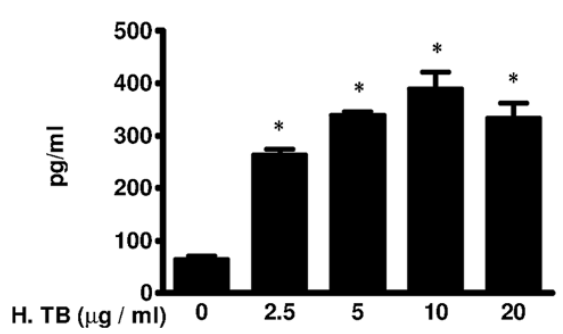

IL-8
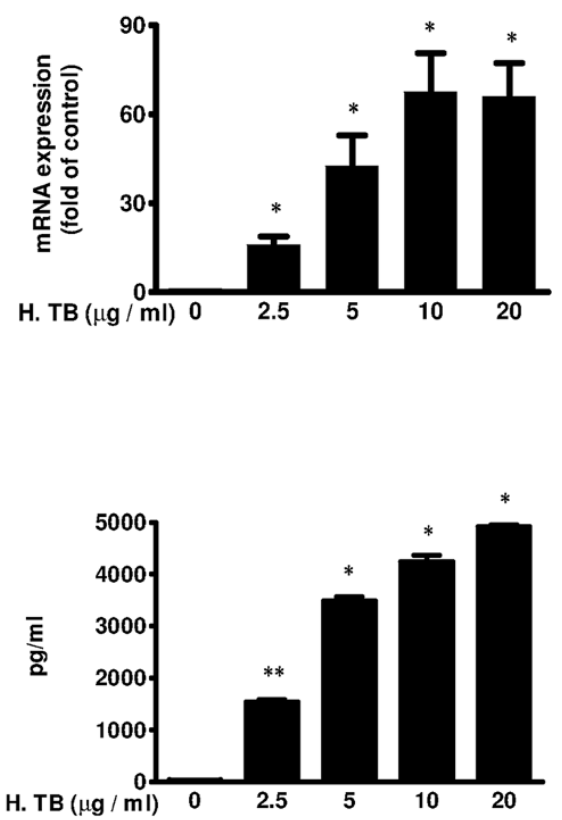

Figure 1 The activation of IP-10 and IL-8 in THP-1 cells treated with H. TB. (A) MTT cytotoxicity assay shows the cell viability of THP-1 cells when treated with $\mathrm{H}$. TB at variable concentrations $(2.5,5,10,20 \mu \mathrm{g} / \mathrm{ml})$ for 6 hours. The cell viability decreased when THP-1 cells treated with $\mathrm{H}$. TB at the concentration of $20 \mu \mathrm{g} / \mathrm{ml}(n=5)$ compared with control. (B) The expression of IP-10 (Left panel) and IL-8 (Right panel) mRNA in THP-1 $(n=5)$ cells was concentration-dependently increased when treated with H. TB for 2 hours, reaching the maximum at $10 \mu \mathrm{g} / \mathrm{ml}$. (C) The release of IP-10 and IL-8 proteins by THP-1 cells $(n=5)$ was concentration-dependently increased when treated with H. TB for 6 hours, reaching the maximum at $10 \mu \mathrm{g} / \mathrm{ml}$. Data are means $\pm \mathrm{SE} .{ }^{*} \mathrm{p}<0.05,{ }^{* *} \mathrm{p}<0.01$ compare with the vehicle control.

\section{Expression of NKRF in THP-1 cells}

Quantification by quantitative RT-PCR demonstrated that NKRF mRNA expression in THP-1 cells increased when treated with $\mathrm{H}$. TB $(2.5,5,10,20 \mu \mathrm{g} / \mathrm{ml})$ for $2 \mathrm{hrs}$ compared with control (Figure 3A). Western Blot analysis (Figure 3B left panel) and confocal microscopic analysis (Figure 3B right panel) revealed a time-dependent increase of NKRF protein in THP-1 cells. The Western blotting (left panel) and confocal image analysis (right panel) for $H$. TB induced NKRF expression revealed a maximal response at concentration of $5 \mu \mathrm{g} / \mathrm{ml}$, when THP-1 cells were treated with $\mathrm{H}$. TB $(2.5,5,10$, and $20 \mu \mathrm{g} / \mathrm{ml})$ for 30 minutes.

NKRF binds the IP-10 and IL-8 promoter sites in H. TB treated THP-1 cells

By binding to the NRE in the IL- 8 promoter, NKRF showed suppression of its basal transcription [28]. As shown in our previous study, there is a specific NRE sequence in the promoter site of IP-10 (Table 1). To this end, ChIP assay analysis with the antibody specific for NKRF was used to study whether NKRF would bind to 


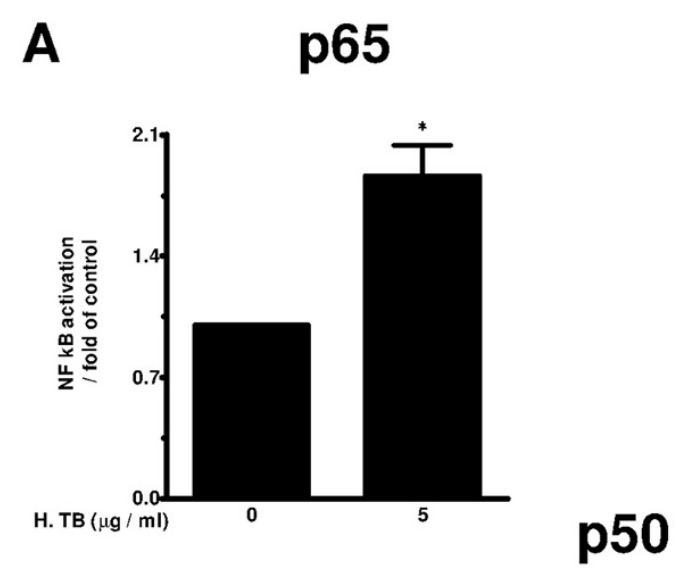

p52

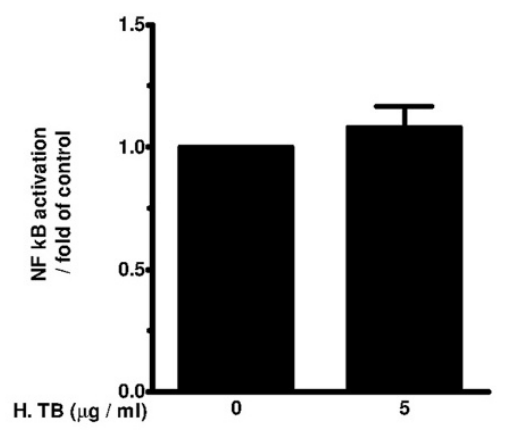

C-Rel

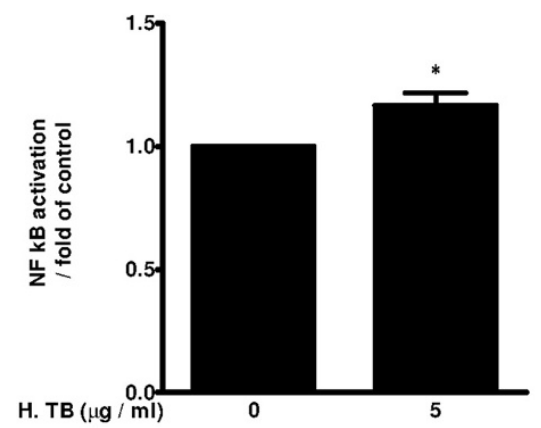

B
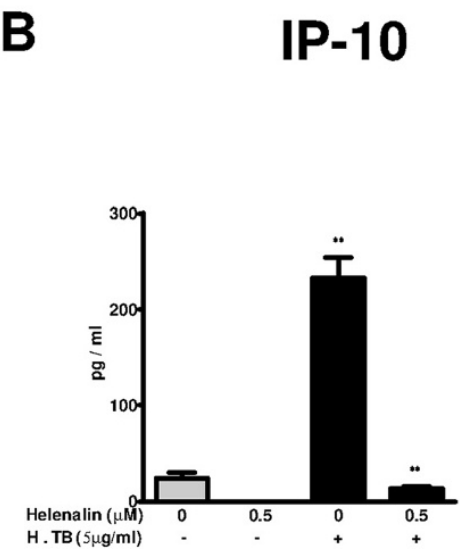

Figure 2 (See legend on next page.)
RelB

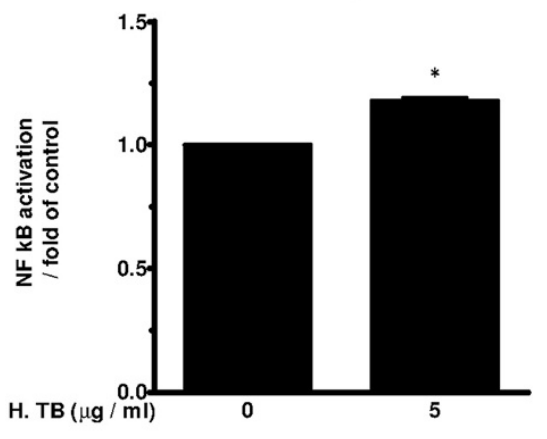

IL-8

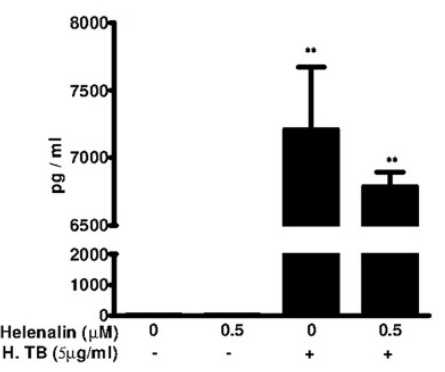


(See figure on previous page.)

Figure $\mathbf{2}$ Increased NF-KB subunits, and the role of Helenalin in the release of IP-10 and IL-8. (A) TransAM assays to measure the NF-KB subunits p65, p52, p50, C-Rel and RelB activities reveals an increase of p65, p52, C-Rel and RelB in THP-1 cells treated with $5 \mu \mathrm{g} / \mathrm{ml} \mathrm{H}$. TB at 2 hour $(n=5)$. (B) The release of IP-10 (left panel) and of IL-8 (right panel) in THP-1 cells $(n=5)$ treated with H. TB for 6 hours was significantly inhibited by a NF-KB specific inhibitor Helenalin $(0.5 \mu \mathrm{M})$. Data are means \pm SE. ${ }^{*} \mathrm{p}<0.05,{ }^{* *} \mathrm{p}<0.01$ compared with corresponding vehicle control.

the NRE sequence in the promoter sites of IP-10 or IL-8. The amount of IP-DNA was determined by RT-qPCR using primer pairs amplifying a region around the NRE site in the IP-10 or IL-8 promoter (Table 2). To demonstrate the site specificity of the assay, a primer pair amplifying an irrelevant site around the 3 '-UTR was also used. IgG controls were used to demonstrate the specificity of the antibody. In the vehicle control, a low but consistently detected enrichment of IP-DNA over background (the IgG control) was observed. In H. TB treated THP-1

\section{A}

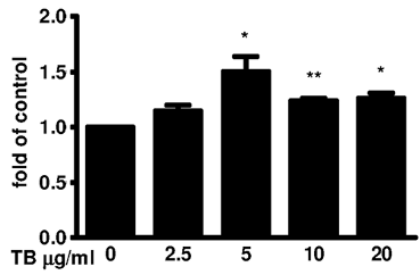

B
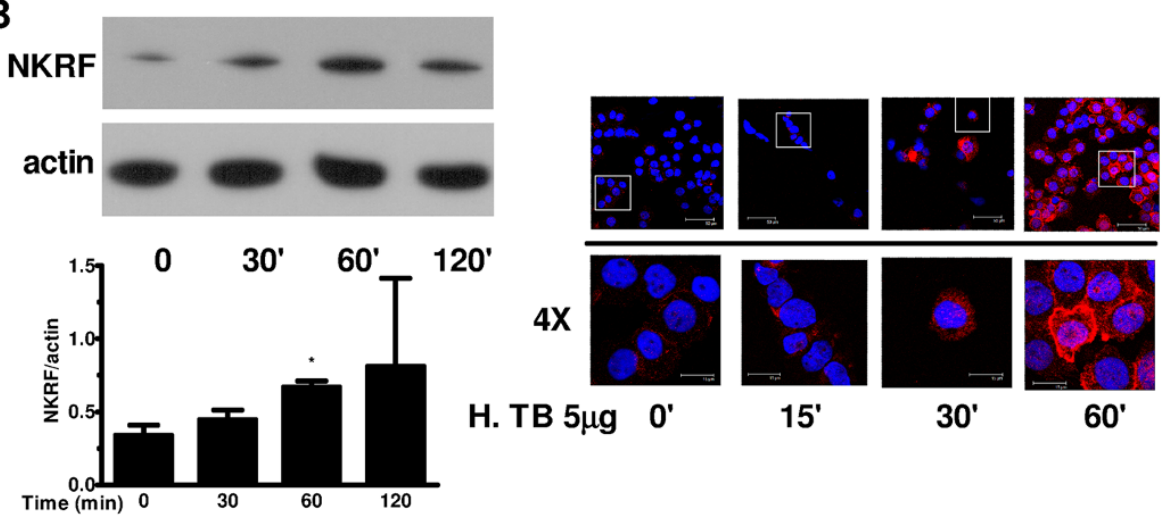

4X
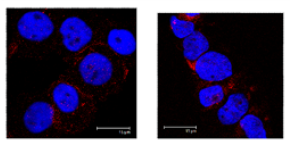

$15^{\prime}$
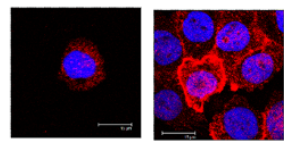

H. TB $5 \mu \mathrm{g} \quad 0^{\prime}$

$30^{\prime}$

$60^{\prime}$

\section{H. T}

C
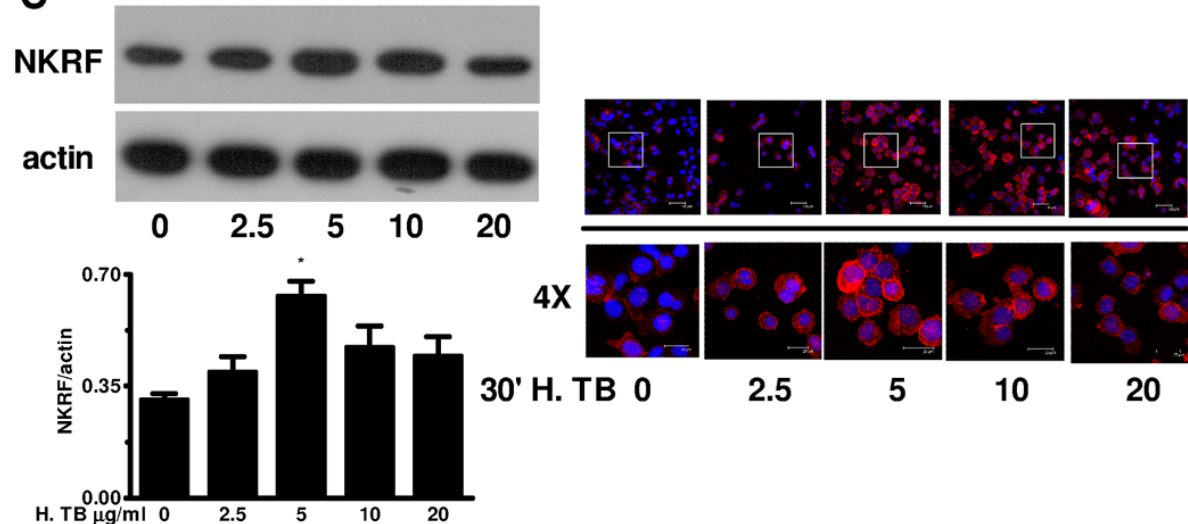

$4 \mathrm{X}$
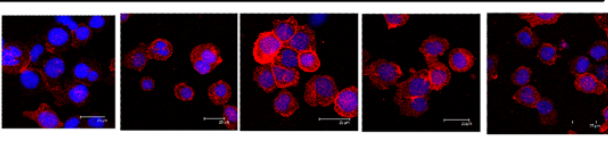

30' H. TB 0

2.5

10

20

Figure 3 Expression of NKRF in THP-1 cells treated with H. TB. (A) Treatment of H. TB for 2 hours increased the expression of NKRF mRNA in THP-1 cells ( $n=5)$ significantly at the concentration of 5, 10 and $20 \mu \mathrm{g} / \mathrm{ml}$. (B) Westen blotting (left panel) and confocal image analysis (right panel) $(n=5)$ of THP-1 cells treated with $\mathrm{H}$. TB at the concentration of $5 \mu \mathrm{g} / \mathrm{ml}$ revealed a time-dependent increase in NKRF expression. (C) The Western blotting (left panel) and confocal image analysis (right panel) $(n=5)$ for $\mathrm{H}$. TB induced NKRF expression revealed a maximal response at concentration of $5 \mu \mathrm{g} / \mathrm{ml}$, when THP-1 cells were treated with $\mathrm{H}$. TB $(2.5,5,10$, and $20 \mu \mathrm{g} / \mathrm{ml})$ for 30 minutes. Data are means \pm SE. ${ }^{*} p<0.05$, ${ }^{* *} \mathrm{p}<0.01$ compared with control. 
Table 1 Sequence comparison of the NRE sites in IP-10 and IL-8 promoters

\begin{tabular}{ll}
\hline Construct gene & NRE sequence \\
\hline IP-10 promoter & $(-503)$ AACTCCTGAGC (-493) \\
IL-8 promoter & $(-1415)$ AATTCCTCTGA $(-1405)$
\end{tabular}

NRE = negative response element; IP-10 = interferon gamma induced protein $10 \mathrm{kd}$; IL-8 = interleukin-8.

cells, the amount of p65 IP-DNA at IP-10 and IL-8 promoters was significantly higher than those of control (Figure 4A). In contrast, there was no significant change in the IP-DNA when the primers for $3^{\prime}$-UTR were used (data not shown). H. TB also induced increased occupancy of NKRF to the promoters at IP-10 and IL-8 in THP-1 cells (Figure 4B). The highest increase was found in $1 \mathrm{hr}$ (Figure $4 \mathrm{C}$ ).

\section{NKRF inhibits H. TB induced release of IP-10 and IL-8 in THP-1 cells}

We conducted in vitro experiments of NKRF knockdown by transfection with siRNA targeting NKRF (NKRF-RNAi) or non-targeting siRNA (scramble RNA) in THP-1 cells. Transfection with NKRF-RNAi for 48 hrs significantly

Table 2 Transcript and sequence of each primer used in real time RT-PCR and ChIP assays

\begin{tabular}{|c|c|}
\hline Transcript & Sequence \\
\hline For RT-PCR & Primer \\
\hline \multirow[t]{2}{*}{ IP-10 } & F: 5'-AGTTAGCAAGGAAAGGTCT-3' \\
\hline & R: 5'-ACATTATAGTGCCAGGT-3' \\
\hline \multirow[t]{2}{*}{$\mid \mathrm{L}-8$} & F: 5'-AGATCTGAAGTGTGATGACTCAGG-3' \\
\hline & R: 5'-GAAGCTTGTGTGCTCTGCTGTCTC-3' \\
\hline \multirow[t]{2}{*}{ NKRF } & F: 5'-AGAAAGATGGGTTGGACT-3' \\
\hline & R: 5'-CTGTGTGGCTCTCGGA-3' \\
\hline \multirow[t]{2}{*}{ GAPDH } & F: 5'-TTCCAGGAGCGAGATCCCT-3' \\
\hline & R: 5'-CACCCATGACGAACATGGG-3' \\
\hline For ChIP assays & Primer \\
\hline \multirow[t]{2}{*}{ NKRF promoter, } & F: 5'-AGGTTCAAGCAGTाTCC-3' \\
\hline & R: 5'-CTGTAATCTCAGCACITTGG-3' \\
\hline \multirow[t]{2}{*}{ IP-10 promoter } & F: 5'-AGGCTGGTCTCAAACT-3' \\
\hline & R: 5'-CCTCCCACATCCAATTACT-3' \\
\hline \multirow[t]{2}{*}{ IL-8 promoter } & F: 5'-GGGCCATCAGTTGCAAATC-3' \\
\hline & R: 5'-TTCCTTCCGGTGGTTCTTC-3' \\
\hline \multirow{2}{*}{$\begin{array}{l}\text { IP-10 3'-untranslated region } \\
\text { (3'-UTR) }\end{array}$} & F: 5'- TTGAGTTATAATTACTTAT-3' \\
\hline & R: 5'-TGAAAAGAAGGGTGAGAAGAG-3' \\
\hline \multirow{2}{*}{$\begin{array}{l}\text { IL-8 3'-untranslated region } \\
\left(3^{\prime}-U T R\right)\end{array}$} & F: 5'-AGGTTCAAGCAGTाTCC-3' \\
\hline & R: 5'-CTGTAATCTCAGCACTITGG-3' \\
\hline
\end{tabular}

$\mathrm{F}=$ forward; $\mathrm{R}=$ reverse; $\mathrm{IP}-10=$ Interferon gamma induced protein $10 \mathrm{kd}$; $\mathrm{IL}-8=$ interleukin-8; NKRF $=\mathrm{NF}-\mathrm{KB}$ repressing factor; $\mathrm{ChIP}=$ chromatin immunoprecipitation. decreased the level of NKRF mRNA compared with scramble $(55.2 \pm 8.0 \%$ of scramble control, $\mathrm{n}=5, \mathrm{p}<0.05$ data not shown). MTT assays showed similar cellular viability between NKRF-RNAi and scramble transfected cells (96.6 $\pm 3.0 \%$ of control, $n=5$, data not shown). Cells after transfection were then treated with or without H. TB for 6 hrs, and the supernatants were collected for ELISA assay. THP-1 cells transfected with NKRF-RNAi released a greater levels of IP-10 and IL-8 proteins with or without $\mathrm{H}$. TB $(5 \mu \mathrm{g} / \mathrm{ml})$ treatment when compared with those transfected with scramble (Figure 5A). These data indicate that endogenous NKRF suppresses basal and $\mathrm{H}$. TB induced IP-10 and IL- 8 production in THP-1 cells.

To delineate the mechanism underlying the up-regulation of NKRF by H. TB, THP-1 cells were transfected with plasmid DNA (p-CMV-vector and p-CMV-NKRF) for $24 \mathrm{hrs}$, then exposed to $\mathrm{H}$. TB. Lower protein levels of IP-10 and IL-8 were produced by p-CMV-NKRF transfected THP-1 cells than $\mathrm{p}-\mathrm{CMV}$-vector transfected cells when exposed to $5 \mu \mathrm{g} / \mathrm{ml}$ of $\mathrm{H}$. TB (Figure $5 \mathrm{~B}$ ). The ChIP assays revealed overexpressions of NKRF by p-CMVNKRF transfection inhibited p65 binding to the promoter sites of IP-10 and IL-8 at basal levels or after H. TB treatment $(5 \mu \mathrm{g} / \mathrm{ml})$ when compared with $\mathrm{p}-\mathrm{CMV}$-vector transfection (Figure 6A). Treatment with $\mathrm{H}$. TB induced recruitment of RNA polymerase II to the promoter sites of IP-10 and IL-8 when compared with vehicle controls (Figure 6B). Transfection with p-CMV-NKRF significantly attenuated $\mathrm{H}$. TB induced recruitment of RNA polymerase II to either IP-10 or IL-8 promoter sites (Figure 6B). These observations suggest that the intracellular NKRF regulates the production of IP-10 and IL- 8 via an inhibition of p65 binding and RNA polymerase II recruitment to both IP-10 and IL-8 promoter sites.

\section{Discussion}

The present study has demonstrated that direct exposure to Mycobacterium TB induces increased mRNA synthesis and release of IP-10 and IL-8 proteins, as well as a concomitant upregulation of NKRF mRNA and proteins in mononuclear cells. The ChIP assay revealed that increased NKRF nuclear translocation was associated with an increased occupancy at the promoter sites of IP-10 and IL-8. Over there, NKRF hindered NF-kB (p65) from binding to the promoter sites, and then prevented RNA polymerase II recruitment resulting in a decrease in mRNA and protein synthesis of IP-10 and IL-8. Knockdown of NKRF by siRNA augmented $H$. TB induced protein release of both IP-10 and IL-8. Furthermore, NKRF overexpression suppressed $\mathrm{H}$. TB induced release of IP-10 and IL-8 proteins. Our results illustrate that NKRF can restrain IP-10 and IL-8 expressions via hindering NF- $\mathrm{kB}$ (p65) and RNA polymerase II from occupancy at the corresponding promoter sites. 

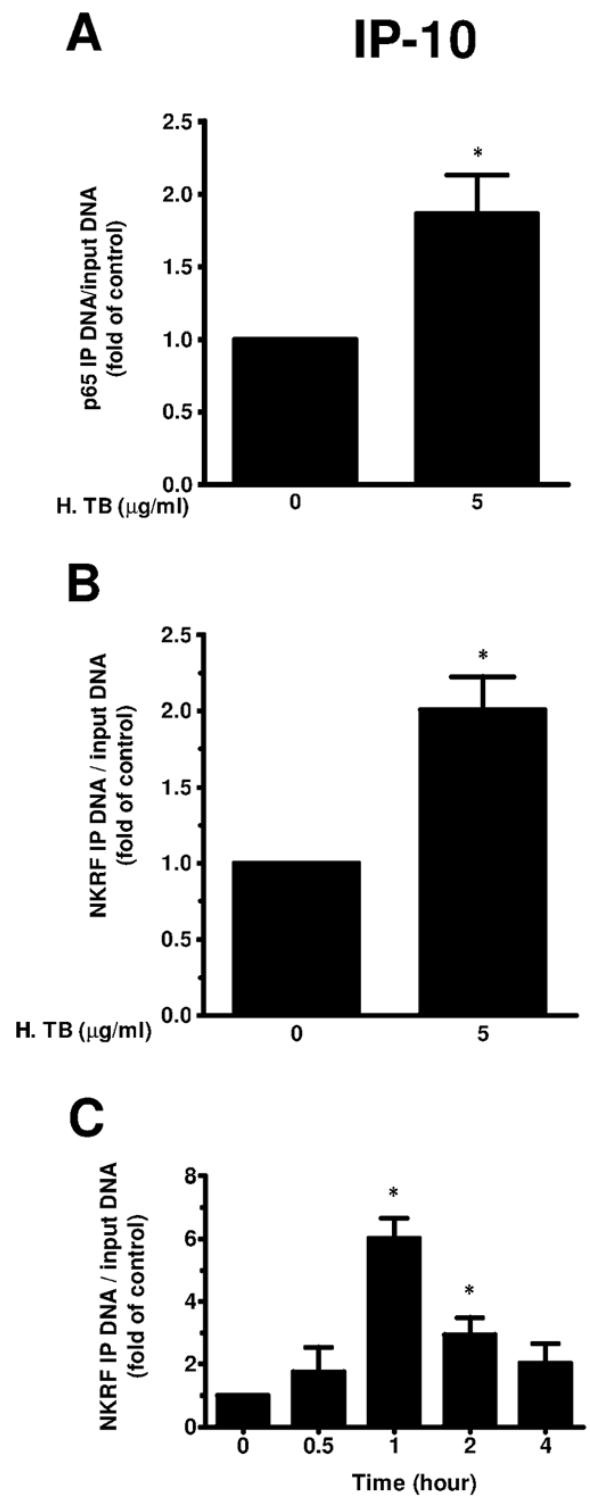

\section{IL-8}
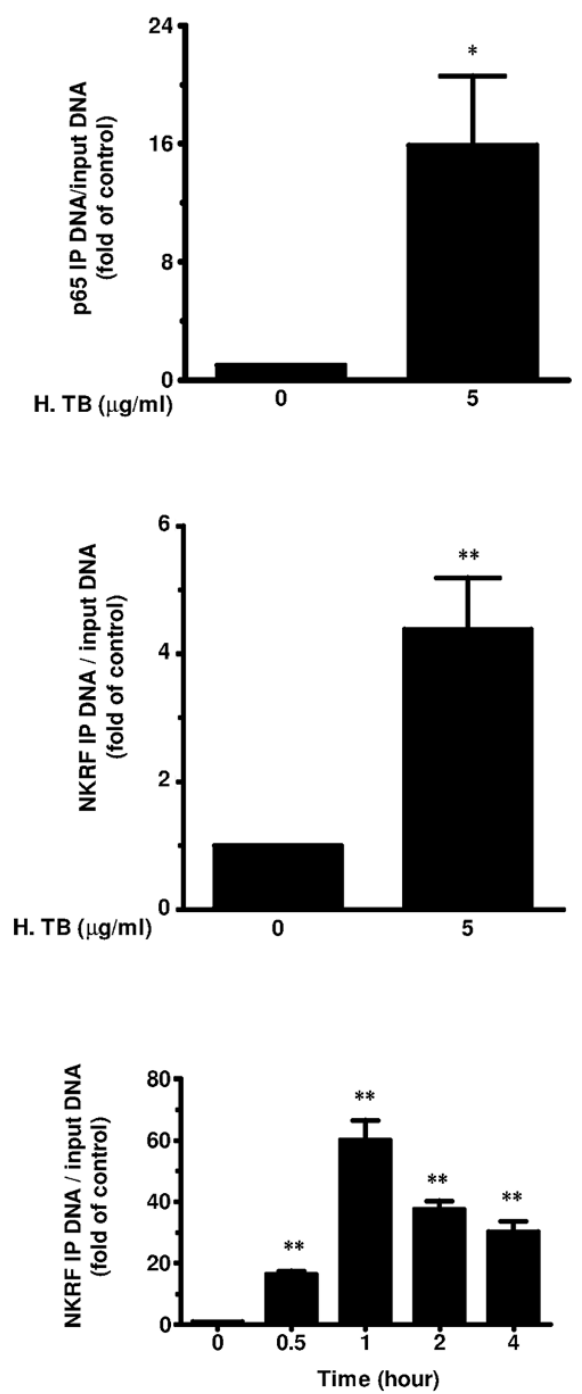

Figure 4 p65 and NKRF binding to IP-10 and IL-8 promoter sites by ChIP assays. (A) The ChIP assays showed a higher binding of p65 to IP-10 (left panel) and IL-8 (right panel) promoter sites in THP-1 cells treated with H. TB $(5 \mu \mathrm{g} / \mathrm{ml})$. (B) The ChIP assays showed a higher binding of NKRF to IP-10 (left panel) and IL-8 (right panel) promoter sites in THP-1 cells treated with H. TB $(5 \mu \mathrm{g} / \mathrm{ml})$ (C) H. TB $(5 \mu \mathrm{g} / \mathrm{ml})$ induced NKRF binding to IP-10 (left panel) and IL-8 (right panel) promoter sites in THP-1 cells is time-dependent. Data are means \pm SE. ${ }^{*} \mathrm{p}<0.05,{ }^{* *} \mathrm{p}<0.01$ compared with control.

Although there are some similarities with the previous published work [13], this study was designed to confirm whether a direct contact of monocytes or alveolar macrophages with Mycobacteria might directly induce NKRF without other immunological modifications as like in vivo. Other immune cells, especially lymphocytes may have primed circulating monocytes or alveolar macrophages even retrieved from normal subjects in this country where TB is highly prevalent and latent TB is difficult to be excluded. Thus, the mechanisms explored in primary cell lines might provide more insight into the up-regulation of
NKRF and its interaction with $\mathrm{NF}-\mathrm{kB}$ in regulation of IP-10 and IL-8 release.

In pulmonary tuberculosis, the encounter between MTb and the innate immune system induces a complicated and sophisticated series of host responses. The next long-term phase of the encounter is played by the activation of the adaptive immune system. An important first step is to recruit intravascular immune cells to the proximity of the infective focus and prepare them for extravasation. In pulmonary tuberculosis, the local generation of chemokines and immune regulation are responsible for the 


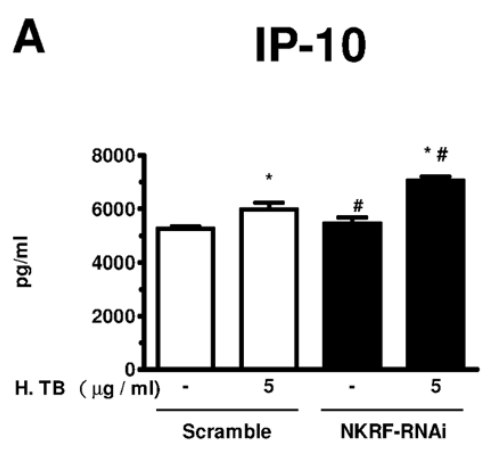

B

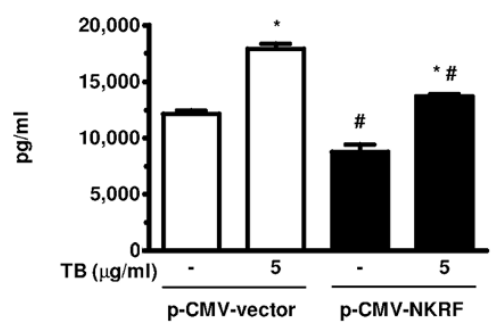

IL-8
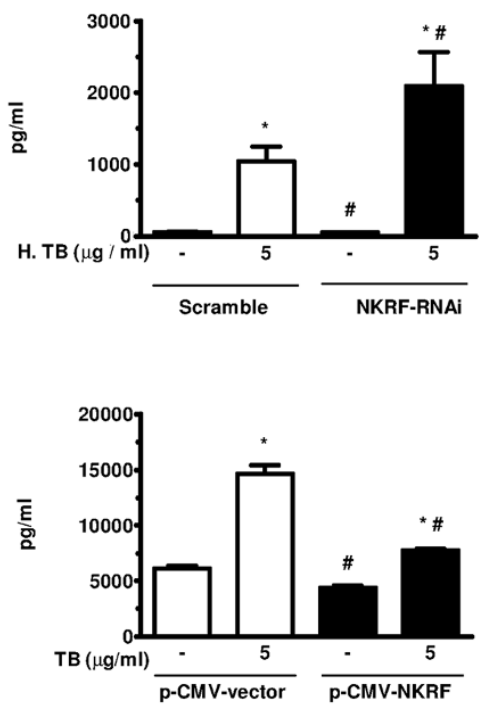

Figure 5 Inhibition of NKRF increased the release of IP-10 and IL-8. (A) THP-1 cells transfected with siRNA targeting NKRF (NKRF-RNAi) for 48 hours significantly enhanced the release of IP-10 (left panel) and IL-8 (right panel) proteins with or without H. TB (5 $\mu \mathrm{g} / \mathrm{ml}$ ) stimulation, when compared with corresponding scramble control (Scramble). (B) THP-1 cells transfected with NKRF plasmid (p-CMV-NKRF) for 24 hours significantly decreased the protein levels of IP-10 (left panel) and IL-8 (right panel) in THP-1 cells with or without H. TB (5 $\mu \mathrm{g} / \mathrm{ml}$ ) stimulation, when compared with corresponding vector control ( $\mathrm{p}-\mathrm{CMV}$-vector). Data are means $\pm \mathrm{SE}$. ${ }^{*} \mathrm{p}<0.05$ compared with the corresponding group without $\mathrm{H}$. TB treatment; $\# \mathrm{p}<0.05$ compared with the corresponding Scramble or vector control group.

recruitment of leukocytes to the site of inflammation and injured site [29]. The increased induction of C-X-C chemokines, IP-10 in MTb infection [9,13] attracts Th1-, Tc1activated lymphocytes and NK cells through CXCR3 [10-12]. IP-10 also can play a role in generation and function of effector $\mathrm{T}$ cells by promoting antigen-specific proliferation and IFN- $\gamma$ secretion $[12,30,31]$. IL-8 is involved in monocyte, lymphocyte, and neutrophil recruitment $[32,33]$, and implicated in granuloma formation and maintenance in TB $[21,34,35]$. The present study demonstrated that direct contacts with MTb induced mononuclear cells to increase synthesis and release of IP-10 and IL-8, indicating IP-10 and IL-8 are very important in the innate immune response and bridges to the adaptive cellular response.

NKRF plays a dual role in IL-1-induced IL-8 transcription [27] and the binding to DNA specifically abolishes the transcriptional activity of the bordering NF- $\mathrm{B}$ B-binding sites by a noncompeting, distance and position-independent mechanism [26]. In our previous study in human airway smooth muscle cells, NKRF inhibited neutrophil elastase induced NF- $\mathrm{kB}$ transactivating activity or directly suppressed the promoter site to modulate IL- 8 synthesis and protein release [36]. In alveolar macrophages and peripheral blood mononuclear cells of pulmonary TB patients, knockdown of NKRF significantly increased IP-10 and IL-8 release [13]. These results suggest NKRF may serve as an endogenous repressor in IP-10 and IL-8 synthesis and release. However, NKRF was found upregulated to repress IP-10 and IL- 8 release only in pulmonary TB patients with high bacterial load [13]. In this study, we have shown $\mathrm{H}$. TB dose-dependently increased NKRF expression in THP-1 cells, significantly at concentrations of $\mathrm{H}$. TB more than $5 \mu \mathrm{g} / \mathrm{ml}$, suggesting the induction of NKRF synthesis might be directly related to exposure to TB bacillus itself or its components.

$\mathrm{MTb}$ and its components also have been reported to cause a constitutive degradation of $\mathrm{I}_{\kappa} \mathrm{B}-\alpha$, leading to NF- $\mathrm{kB}$ activation in monocytes from TB patients [37]. TransAM assay in the present study showed $\mathrm{H}$. TB exposure induced activation of a variety of NF- $\mathrm{kB}$ subunits, predominantly p65. A specific NF- $\mathrm{kB}$ inhibitor Helenalin suppressed H. TB induced IP-10 and IL- 8 release, suggesting both IP-10 and IL-8 release were mainly mediated via NF- $\mathrm{kB}$ activation, especially p65 subunit. Our previous study has indicated that NF- $\mathrm{kB}$ activation induces NKRF synthesis through NF- $\mathrm{kB}$ subunit p65 binding to the NKRF promoter to transcriptionally activate NKRF mRNA synthesis [36]. Thus, a direct contact with MTb induces NF-kB activation leading to up-regulation of IP-10 and IL- 8 synthesis and release in mononuclear cells. If bacterial load is high enough, NF- $\mathrm{kB}$ activation may also induce a concomitant 


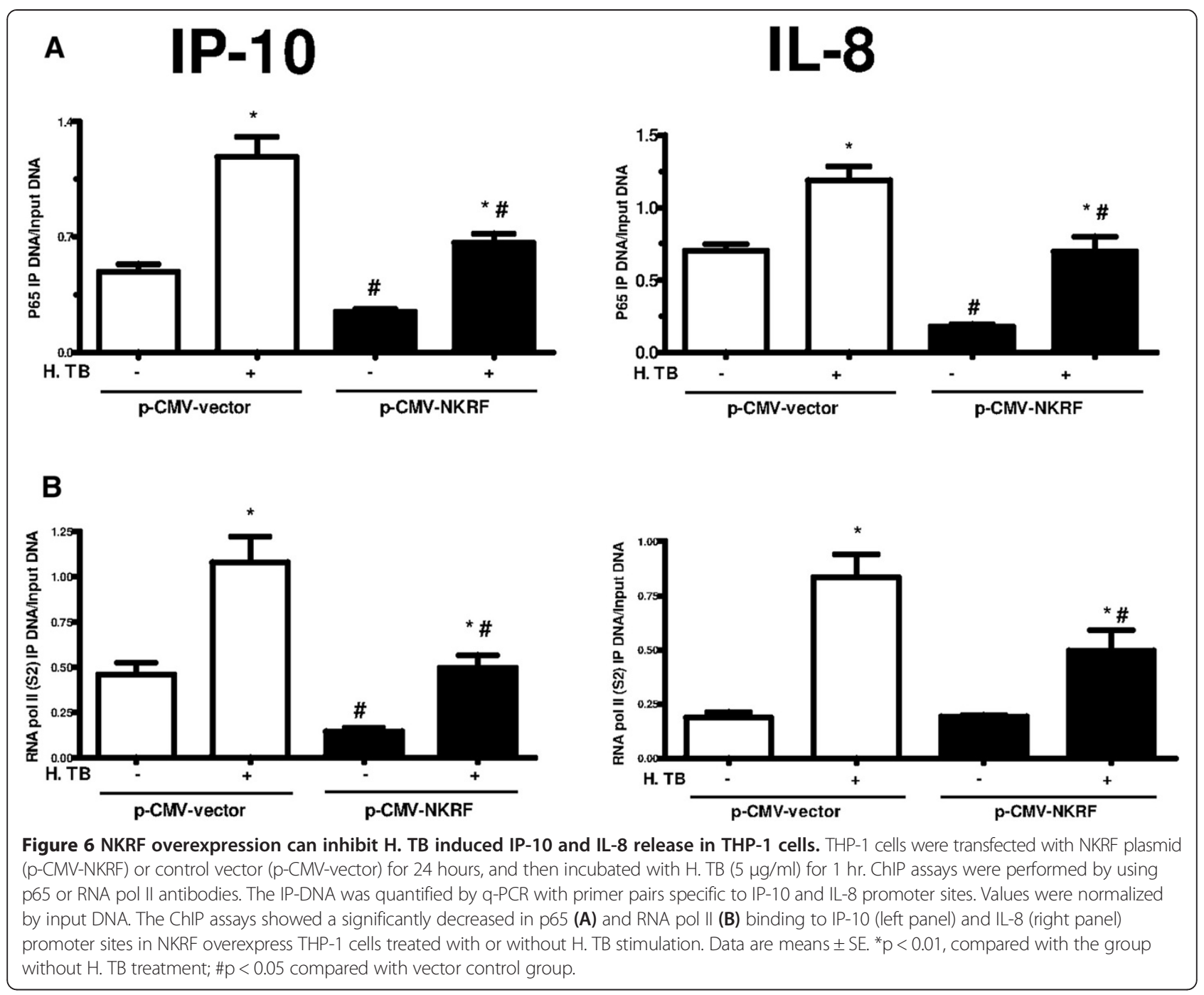

increase in NKRF that represses the synthesis and release of IP-10 and IL-8.

A further study to investigate whether $\mathrm{H}$. TB induced up-regulation of NKRF is mediated through NF- $\mathrm{kB}$ is hindered by a concomitant NF- $\mathrm{KB}$ activation-increased oxidative stress induced by $\mathrm{H}$. TB stimulation. The high levels of oxidative stress degrade NKRF as we have reported in monocytes of COPD patients [38]. Thus, modification of NF- $\mathrm{kB}$ activation by pharmacological inhibitors or by gene knock down or over-expression may concomitantly influence the levels of intracellular oxidants, leading to a difficulty in precisely representing the causal-effect on NKRF synthesis in this experimental model. In addition, we have also found distinct subunits of NF-kB are activated by different concentrations of $\mathrm{H}$. TB. Whether distinct NF- $\mathrm{B}$ subunits mediate differential effects of $\mathrm{H}$. TB on NKRF expression is currently under study.

Our data display a great difference of increased activities of p65 and NKRF to promoter of IP-10 and IL-8, i.e.
NF- $\mathrm{kB}$ p65 expression was 2-fold for IP-10 and 15-fold for IL-8. The possible explanation is that the IL- 8 promoter is predominantly activated by the induction of $N F-\kappa B$ complex containing p65, though either AP-1 or C/EBP- $\beta$ may also play supporting roles $[39,40]$. However, IP-10 promoter is predominantly activated by an interferonstimulated response element, although there is also an existent NF- $\mathrm{KB}$ responsive site that binds a p65 homodimer. IP-10 gene activation is less dependent on NF-kB p65, but only in maximal IP-10 expression, cooperation between two sites is required [41]. Thus, the binding activities of NF-kB to promoter of IP-10 might be much lower than those to IL-8 promoter.

Our ChIP assay used the same primer pairs (Table 2) to amplify a region around the NRE site in the promoters of IP-10 and IL-8. There was an increase in NKRF occupancy at IP-10 and IL- 8 promoter sites in the H. TB treated group, suggesting an inhibition at the transcriptional initiation. RNA interference and plasmid overexpression were performed to explore a link between NKRF 
expression and it's repressive effect on IP-10 and IL-8 synthesis. In THP-1 cells, knockdown of NKRF augmented $\mathrm{H}$. TB induced IP-10 and IL-8 release, but overexpression of NKRF attenuated the responses. Furthermore, in ChIP assay we found that NKRF overexpression restrained p65 binding and RNA polymerase II recruitment to IP-10 and IL-8 promoter sites. However, NKRF overexpression did suppress the baseline IP-10 and IL- 8 release, and $\mathrm{H}$. TB still induced IP-10 and IL-8 release from THP-1 cells. Therefore, we suggest NF- $\mathrm{kB}$ might be also involved in the basal release of IP-10 and IL-8. H. TB induced IP-10 and IL-8 release is not completely inhibited by NKRF. H. TB may act through NF-kB-independent pathways, such as AP- 1 or $C / E B P-\beta$ or interferon-stimulated response elements to induce IL-8, or IP-10 release. Thus, NKRF in THP-1 cells may serve as an endogenous repressor to prevent robust increase in $\mathrm{H}$. TB induced IP-10 and IL-8 release by interference with NF- $\mathrm{B}$ transcriptional activity.

\section{Conclusions}

The results of this in vitro study are consistent with the findings of our previous study that NKRF up-regulated expression in alveolar macrophages and peripheral blood monocytes of active pulmonary TB patients represses IP-10 and IL- 8 synthesis and release. This study further delineates the underlying mechanisms that a direct contact with MTb induces NKRF synthesis and nuclear translocation, binding to NRE in the promoter sites of IP-10 and IL-8. Over there, NKRF interferes with NF-кB (p65) binding and RNA polymerase II recruitment, leading to a repressive effect on IP-10 and IL-8 synthesis.

\section{Abbreviations \\ ChIP: Chromatin immunoprecipitation; ECL: Enhanced chemiluminescence; \\ FCS: Fetal calf serum; H. TB: heated mycobacterium tuberculosis; IL-8: interleukin-8; IP-10: gamma interferon induced protein 10 kd; MTb: Mycobacteria \\ Tuberculosis; NF-kB: Nuclear factor kappa B; NKRF: Nuclear factor kappa B repressing factor; NRE: negative regulatory element; PBS: Phosphate-buffered saline; q-PCR: Quantitative polymerase chain reaction; RT-PCR: Reverse transcription-polymerase chain reaction; siRNA: Small interfering RNA; TB: Tuberculosis.}

\section{Competing interests}

The authors declare that they have no competing interests related to this work.

\section{Authors' contributions}

$\mathrm{KHH}, \mathrm{CHW}, \mathrm{HPK}$ and $\mathrm{CHL}$ designed and written this study. $\mathrm{KHH}$ performed this study. All authors read and approved the final manuscript.

\section{Acknowledgements}

The work was performed at the Department of Thoracic Medicine, Chang Gung Memorial Hospital, Taoyuan, Taiwan.

\footnotetext{
Author details

${ }^{1}$ Graduate Institute of Medical Sciences, College of Medicine, Taipei Medical University, 250 Wu-Hsing Street, Taipei 110, Taiwan. ${ }^{2}$ Pulmonary Medicine Research Center, Chang Gung Memorial Hospital, Taipei, Taiwan. ${ }^{3}$ Department of Thoracic Medicine, Chang Gung Memorial Hospital, 199 Tun-Hwa North Road, Taipei, Taiwan.
}

Received: 22 May 2014 Accepted: 25 July 2014

Published: 19 August 2014

\section{References}

1. Murry JF: A century of tuberculosis. Am J Respir Crit Care Med 2004, 169:1181-1186.

2. Gupta R, Espinal MA, Raviglione MC: Tuberculosis as a major global health problem in the 21st century: a WHO perspective. Semin Respir Crit Care Med 2004, 25:245-253.

3. Frieden TR, Sterling TR, Munsiff SS, Watt CJ, Dye C: Tuberculosis. Lancet 2003, 362:887-899.

4. Saunders BM, Cooper AM: Restraining mycobacteria: role of granulomas in mycobacterial infections. Immunol Cell Biol 2000, 78:334-341.

5. Flynn JL, Chan J: Immunology of tuberculosis. Annu Rev Immunol 2001, 19(1):93-129.

6. Orme IM, Cooper AM: Cytokine/chemokine cascades in immunity to tuberculosis. Immunol Today 1999, 20:307-312.

7. Sadek MI, Sada E, Toossi Z, Schwander SK, Rich EA: Chemokines induced by infection of mononuclear phagocytes with mycobacteria and present in lung alveoli during active pulmonary tuberculosis. Am J Respir Cell Mol Biol 1998, 19:513-521.

8. Riedel DD, Kaufmann SHE: Chemokine secretion by human polymorphonuclear granulocytes after stimulation with mycobacterium tuberculosis and lipoarabinomannan. Infect Immun 1997, 65:4620-4623.

9. Kuarshima K, Mukaida N, Fujimura M, Yasui M, Nakazumi Y, Matsuda T, Matsushima K: Elevated chemokine levels in bronchoalveolar lavage fluid of tuberculosis patients. Am J Resp Crit Care Med 1997, 155:1474-1477.

10. Kaplan G, Luster AD, Hancock G, Cohn ZA: The expression of a gamma interferon -induced protein (IP-10) in delayed immune responses in human skin. J Exp Med 1987, 166:1098-1108.

11. Gangur V, Simons FE, Hayglass KT: Human IP-10 selectively promotes dominance of polyclonally activated and environmental antigen-driven IFN-gamma over IL-4 responses. FASEB J 1998, 12:705-713.

12. Farber JM: Mig and IP-10: CXC chemokines that target lymphocytes. J Leukoc Biol 1997, 61:246-257.

13. Huang $\mathrm{KH}$, Wang $\mathrm{CH}$, Lee KY, Lin SM, Lin CH, Kuo HP: NF-KB repressing factor inhibits chemokine synthesis by peripheral blood mononuclear cells and alveolar macrophages in active pulmonary tuberculosis. PLoS One 2013, 8:e77789.

14. Juffermans NP, Verbon A, Van Deventer SJH, Van Deutekom H, Belisle JT, Ellis ME, Speelman P, Van Der Poll T: Elevated chemokine concentrations in sera of human immunodeficiency virus (HIV)-seropositive and HIVseronegative patients with tuberculosis: a possible role for mycobacterial lipoarabinomannan. Infect Immun 1999, 67:4295-4297.

15. Sauty A, Dziejman M, Taha RA, Larossi AS, Neote K, Garcia-Zepeda EA, Hamid Q, Luster AD: The T cell-specific CXC chemokines IP-10, Mig, and ITAC are expressed by activated human bronchial epithelial cells. J Immunol 1999, 162:3549-3558.

16. Keane MP, Arenberg DA 3rd, Lynch JP, Whyte Rl, lannettoni MD, Burdick MD, Wilke CA, Morris SB, Glass MC, DiGiovine B, Kunkel SL, Strieter RM: The CXC chemokines, IL- 8 and IP-10, regulate angiogenic activity in idiopathic pulmonary fibrosis. J Immunol 1997, 159:1437-1443.

17. Friedland JS, Remick DG, Shattock R, Griffin GE: Secretion of interleukin-8 following phagocytosis of mycobacterium tuberculosis by human monocyte cell lines. Eur J Immunol 1992, 22:1373-1378.

18. Zhang Y, Broser M, Cohen H, Bodkin M, Law K, Reibman J, Rom WN: Enhanced interleukin-8 release and gene expression in macrophages after exposure to mycobacterium tuberculosis and its components. J Clin Invest 1995, 95:586-592.

19. Ma X, Reich RA, Wright JA, Tooker HR, Teeter LD, Musser JM, Graviss EA: Association between interleukin-8 gene alleles and human susceptibility to tuberculosis disease. J Infect Dis 2003, 188:349-355.

20. Law KF, Jagirdar J, Weiden MD, Bodkin M, Rom WN: Tuberculosis in HIV-positive patients: cellular response and immune activation in the lung. Am J Respir Crit Care Med 1996, 153:1377-1384.

21. Larsen CG, Thomsen MK, Gesser B, Thomsen PD, Deleuran BW, Nowak J, Skodt V, Thomsen HK, Deleuran M, Thestruo-Pedersen K: The delayed-type hypersensitivity reaction is dependent on IL-8. Inhibition of a tuberculin skin reaction by an anti-IL-8 monoclonal antibody. J Immunol 1995, 155:2151-2157. 
22. O'Kane CM, Boyle JJ, Horncastle DE, Elkington PT, Friedland JS: Monocytedependent fibroblast CXCL8 secretion occurs in tuberculosis and limits survival of mycobacteria within macrophages. J Immunol 2007, 178:3767-3776.

23. Melissa IW, Lynette HT, Jon SF: Pulmonary epithelial cells are a source of IL-8 in the response to Mycobacterium tuberculosis: essential role of IL-1 from infected monocytes in a NF-KB-dependent network. J Immunol 1999, 163:3936-3947.

24. Tang NL, Fan HP, Chang KC, Ching JK, Kong KP, Yew WW, Kam KM, Leung CC, Tam CM, Blackwell J, Chan CY: Genetic association between a chemokine gene CXCL-10 (IP-10, interferon gamma inducible protein 10) and susceptibility to tuberculosis. Clin Chim Acta 2009, 406:98-102.

25. Feng $X$, Guo Z, Nourbakhsh M: Identification of a negative response element in the human inducible nitric-oxide synthase (hiNOS) promoter: the role of NF-kappa B repressing factor (NRF) in basal repression of the hiNOS gene. Proc Natl Acad Sci U S A 2002, 99:14212-14217.

26. Nourbakhsh M, Hauser $\mathrm{H}$ : Constitutive silencing of IFN-beta promoter is mediated by NRF (NF-kappaB-repressing factor), a nuclear inhibitor of NF-kappaB. Embo J 1999, 18:6415-6425.

27. Lee KY, Ito K, Hayashi R, Jazrawi EPI, Barnes PJ, Adcock IM: NF-KB and activator protein 1 response elements and the role of histone modifications in IL-1 $\beta$-induced TGF- $\beta 1$ gene transcription. J Immunol 2006, 176:603-615.

28. Nourbakhsh M, Kalble S, Dorrie A, Hauser H, Resch K, Kracht M: The NF-KB repressing factor is involved in basal repression and interleukin (IL)-1-induced activation of IL-8 transcription by binding to a conserved NF-KB-flanking sequence element. J Biol Chem 2001, 276:4501-4508.

29. Baggiolini M, Dewald B, Moser B: Human chemokines: an update. Annu Rev Immunol 1997, 15:675-705.

30. Neville LF, Mathiak G, Bagasra O: The immunobiology of interferongamma inducible protein $10 \mathrm{kD}$ (IP-10): a novel, pleiotropic member of the C-X-C chemokine superfamily. Cytokine Growth Factor Rev 1997, 8:207-219.

31. Dufour JH, Dziejman M, Liu MT, Leung JH, Lane TE, Luster AD: IFN-gammainducible protein 10 (IP-10; CXCL10)-deficient mice reveal a role for IP-10 in effector T cell generation and trafficking. J Immuno/ 2002, 168:3195-3204.

32. Broug HE, Toews GB, Van IJF, Strieter RM, Kunkel SL, Paine R, Standiford TJ: Alveolar macrophages are required for protective pulmonary defenses in murine Klebsiella pneumonia: elimination of alveolar macrophages increases neutrophil recruitment but decreases bacterial clearance and survival. Infect Immun 1997, 65:1139-1146.

33. Tsai WC, Strieter RM, Mehrad B, Newstead MW, Zeng X, Standiford TJ: CXC chemokine receptor CXCR2 is essential for protective innate host response in murine pseudomonas aeruginosa pneumonia. Infect Immun 2000, 68:4289-4296.

34. Gerszten RE, Garcia ZEA, Lim YC: MCP-1 and IL-8 trigger firm adhesion of monocytes to vascular endothelium under flow conditions. Nature 1999, 398:718-723.

35. Algood HM, Chan J, Flynn JL: Chemokines and tuberculosis. Cytokine Growth Factor Rev 2003, 14:467-477.

36. Ho SC, Lee KY, Chan YF, Kuo LW, Ito K, Adcock IM, Chen BC, Sheu JR, Lin CH, Kuo HP: Neutrophil elastase represses IL-8/CXCL8 synthesis in human airway smooth muscle cells through induction of NF-kappa B repressing factor. J Immunol 2009, 183:411-420.

37. Toossi Z, Hamilton BD, Phillips MH, Averill LE, Ellner JJ, Salvekar A: Regulation of nuclear factor-kappa B and its inhibitor I kappa B-alpha/ MAD-3 in monocytes by Mycobacterium tuberculosis and during human tuberculosis. J Immunol 1997, 159:4109-4116.

38. Lee KY, Ho SC, Tseng YH, Wang CH, Huang CD, Lin SM, Lo YL, Kuo HP. Reduced NF-KB repressing factor: a link toward systemic inflammation in COPD. Eur Respir J 2012, 40:863-873.

39. Kunsch C, Rosen CA: NF-kB subunit-specific regulation of the interleukin-8 promoter. Mol Cell Bio/ 1993, 13:6137-6146.
40. Kunsch C, Lang RK, Rosen CA, Shannon MF: Synergistic transcriptional activation of the IL-8 gene by NF-KB p65 (RelA) and NF-IL-6. J Immunol 1994, 153:153-164.

41. Majumder S, Zhou LZ, Chaturvedi P, Babcock G, Aras S, Ransohoff RM: Regulation of human IP-10 gene expression in astrocytoma cells by inflammatory cytokines. J Neurosci Res 1998, 54:169-180.

doi:10.1186/s12929-014-0071-5

Cite this article as: Huang et al.: NF-KB repressing factor downregulates basal expression and mycobacterium tuberculosis induced IP-10 and IL8 synthesis via interference with NF-KB in monocytes. Journal of Biomedical Science 2014 21:71.

\section{Submit your next manuscript to BioMed Central and take full advantage of:}

- Convenient online submission

- Thorough peer review

- No space constraints or color figure charges

- Immediate publication on acceptance

- Inclusion in PubMed, CAS, Scopus and Google Scholar

- Research which is freely available for redistribution

Submit your manuscript at www.biomedcentral.com/submit
C) Biomed Central 